\title{
STUDI PEMBUATAN ROTI MANIS KUKUS DARI CAMPURAN TEPUNG TERIGU DENGAN TEPUNG PISANG NANGKA
}

\author{
Susmawida, S.TP ${ }^{(1)}$ dan Retti Ninsix, S.TP., MP ${ }^{(2)}$ \\ (1)Alumni Teknologi Pangan Faperta UNISI \\ (2)Dosen Teknologi Pangan Faperta UNISI
}

\begin{abstract}
Abstrak
Penelitian yang brjudul Studi Pembuatan Roti Manis Kukus Dari Campuran Tepung Terigu Dengan Tepung Pisang Nangka bertujuan untuk mendapatkan komposisi yang tepat pada pencampuran tepung terigu dengan tepung pisang nangka dalam pengolahan roti manis kukus. Penelitian ini telah dilakukan secara eksperimen dengan menggunakan Rancangan Acak Lengkap (RAL) dengan 5 perlakuan dan 3 ulangan. Adapun perlakuan dalam penelitian ini adalah A(Tepung pisang nangka $10 \%$, tepung terigu 90\%), B (Tepung pisang nangka 20\%, tepung terigu $80 \%$ ), C (Tepung pisang nagka $30 \%$, tepung terigu 70\%), D(Tepung pisang nangka $40 \%$, tepung terigu $60 \%$ ), $\mathrm{E}$ (Tepung pisang nangka 50\%, tepung terigu 50\%).

Hasil terbaik untuk kadar air diperoleh pada perlakuan A (Tepung Pisang Nangka 10\% : Tepung Terigu 90\%) dengan kadar air 29,00 \%, kadar abu 0,54\%, dan kadar protein $9,94 \%$, dan uji organoleftik warna 3,20\%, aroma 3,45\%, tekstur $2,95 \%$ dan rasa $2,90 \%$.
\end{abstract}

Kata kunci : Tepung pisang nangka, tepung terigu, roti manis kukus

\section{PENDAHULUAN}

Pisang merupakan buah-buahan yang tidak bersifat musiman dan selalu tersedia sepanjang tahun, sehingga mudah untuk mendapatkannya. Produksi pisang di daerah Indragiri Hilir cukup besar sehingga harus ada cara untuk menanggulangi produksi buah pisang yang tidak terpasarkan dan belum sepenuhnya dimanfaatkan, sementara pisang termasuk buah-buahan yang mudah mengalami pembusukan, maka perlu adanya usaha untuk pengembangan potensi dan pendayagunaan agar dapat meningkatkan nilai ekonominya. Pembuatan tepung pisang dapat memanfaatkan produksi pisang yang melimpah dan menambah nilai jual dari olahan pisang itu sendiri. Berdasarkan data Badan Pusat Statistik (BPS) Indragiri Hilir produksi pisang tahun
2011 di Kabupaten Indragiri Hilir berjumlah 1.841,50 ton per tahun.

Pembuatan tepung pisang bertujuan selain untuk memperpanjang daya awet tanpa mengurangi nilai gizi pisang, juga untuk mempermudah dan memperluas pengembangan pemanfaatan pisang sebagai bahan makanan seperti untuk kue, keripik dan roti.

Roti merupakan produk olahan yang telah lama dikenal oleh masyarakat dan telah menjadi makanan pokok kedua setelah nasi. Roti memiliki berbagai kelebihan dibandingkan dengan produk pangan lainnya, selain awet, roti juga lebih mudah di dalam penyajiannya, serta kandungan gizinya yang cukup tinggi. Selama ini bahan baku pembuatan roti adalah tepung terigu yang terbuat dari gandum, namun dapat disubtitusi dengan tepung yang mengandung karbohidrat lainnya. 
Terkait dengan penambahan tepung selain tepung terigu dalam pembuatan roti maka perlu perbandingan yang tepat. Menurut De Man (1997), Penambahan tepung tambahan dalam jumlah yang besar dari berat tepung dasar yang digunakan dalam pembutan roti maka dapat mengurangi mutu dari roti. Akan tetapi belum ditemukannya formulasi dan metode yang tepat dalam menghasilkan roti dari campuran tepung pisang nangka yang optimal. Berdasarkan penelitian Amarilia. $\mathrm{H}$. (2011), dengan perbandingan tepung sukun $10 \%$ dan tepung terigu 90\% menghasilkan roti manis kukus yang memberikan hasil terbaik terhadap rasa, warna, aroma dan tekstur yang lembut.

Berdasarkan penjelasan diatas, maka penulis telah melakukan penelitian ini dengan judul " Studi Pembuatan $\$$ Manis Kukus dari Campuran Tepłag Terigu dengan Tepung Pisang Nangka".

\section{Perumusan Masalah}

Selama ini pembuatan roti manis dengan menggunakan tepung terigu dan untuk mengurangi ketergantungan dengan tepung terigu perlu alternatif lain dengan cara penambahan bahan baku yang sama-sama mengandung karbohidrat seperti mengolah pisang menjadi tepung pisang. Pisang merupakan hasil perkebunan yang nilai jual nya relatif rendah, untuk itu perlu diolah menjadi produk olahan makanan yang disukai masyarakat dan dapat meningkatkan nilai ekonominya.

Namun perbandingan yang tepat antara tepung terigu dengan tepung pisang nangka didalam pengolahan roti manis kukus belum diketahui. Berdasarkan hal ini telah dilakukan penelitian dengan judul "Studi Pembuatan Roti Manis Kukus dari Campuran Tepung Terigu dengan Tepung Pisang Nangka".

\section{Tujuan penelitian}

Tujuan dari penelitian ini adalah: (1) untuk mengetahui perbandingan yang tepat antara tepung terigu dan tepung pisang nangka sebagai bahan baku pembuatan roti manis kukus, dan (2) untuk memanfaatkan pisang nangka sebagai bahan makanan seperti roti.

\section{Manfaat penelitian}

Manfaat dari penelitian ini adalah: (1) sebagai sumber informasi dan pengetahuan pada pembuatan roti manis kukus, dan (2) diversifikasi produk olahan roti manis berbahan baku tepung terigu dengan campuran tepung pisang nangka.

\section{METODE PENELITIAN}

\section{Bahan}

Bahan-bahan yang digunakan adalah pisang nangka, tepung terigu, yeast (fermipan), garam, mentega, gula, susu bubuk, telur, air, selai nenas, aquades, $\mathrm{Zn}, \mathrm{NaOH}(0,1 \mathrm{~N}), \mathrm{H}_{2} \mathrm{SO}_{4}$, $\mathrm{HCL}(0,1 \mathrm{~N}), \mathrm{K}_{2} \mathrm{SO}_{4} 4 \%$, fenolptalein, dan $\mathrm{CuSO}_{4-5} \mathrm{H}_{2} \mathrm{O}$.

\section{Alat}

Alat yang digunakan dalam penelitian adalah pisau, panci, talenan, slicer, sendok, ayakan, tepung, kompor, baskom, gelas ukur, timbangan analitik, timbangan kasar, mesin penggiling, blower, kukusan, wadah aluminium, loyang kue, mixer, kain penutup, cawan porselen, desikator, muffle furnance,labu kjedhal, dan labu suling.

\section{Penelitian}

Rancangan percobaan yang digunakan dalam penelitian ini adalah Rancangan Acak Lengkap (RAL) dengan perlakuan campuran tepung terigu dan tepung pisang nangka yang 
berbeda perlakuan yang berbeda, perlakuannya adalah sebagai berikut:
$\mathrm{A}=$ Formulasi tepung pisang nangka $10 \%$ : tepung terigu $90 \%$
$\mathrm{B}=$ Formulasi tepung pisang nangka $20 \%$ : tepung terigu $80 \%$
$\mathrm{C}=$ Formulasi tepung pisang nangka $30 \%$ : tepung terigu $70 \%$
$\mathrm{D}=$ Formulasi tepung pisang nangka $40 \%$ : tepung terigu $60 \%$
$\mathrm{E}=$ Formulasi tepung pisang nangka $50 \%$ : tepung terigu $50 \%$

Setiap perlakuan diulang sebanyak 3 kali sehingga diperoleh 15 sampel percobaan. Data hasil pengamatan dianalisis menggunakan analisis keragaman (analysis of variance) pada taraf nyata $5 \%$. Bila terdapat beda nyata yaitu $\mathrm{F}$ hitung lebih besar dari $\mathrm{F}$ tabel maka diuji lanjut dengan uji Beda Nyata Terkecil (BNT) pada taraf yang sama yaitu $5 \%$ (Hanafiah, 2005).

Model rancangan yang digunakan pada penelitian ini adalah Yijk $=\mu+\mathrm{P} i+\mathrm{E} i j$

\section{Keterangan :}

Yij = Hasil pengamatan terhadap penambahan tepung pisang nangka (1-5) dalam pembuatan roti manis kukus dengan ulangan ${ }_{(1-3)}$.

$\mu \quad=$ Rata - rata / nilai tengah umum

$\mathrm{Pi}=$ pengaruh penambahan tepung pisang nangka (1-5) pada ulangan (1-3)

Eij = Galat Pengaruh penambahan tepung pisang nangka (1-5) pada ulangan (1-3)

\section{Pelaksanaan Penelitian}

$$
\text { Pembuatan Tepung Pisang }
$$

Nangka (Antarlina Merangkap 2011 yang telah dimodifikasi). Pembuatan tepung pisang nangka hampir sama dengan pembuatan tepung pisang pada umumnya, dimana proses pembuatannya sebagai berikut:

1. Persiapan bahan baku/sortasi
Pisang yang akan digunakan adalah pisang nangka yang sudah matang berwarna hijau muda dan setiap sudutnya berisi penuh serta memiliki daging berwarna putih, segar dan tidak cacat.

2. Pengukusan

Untuk menghasilkan tepung pisang yang berwarna putih, maka pengaruh getah harus diminimalkan dengan cara mengukus buah pisang mentah selama 10-20 menit sebelum pengupasan. Lama pengukusan dapat lebih singkat tergantung dari jumlah buah yang dikukus.

\section{Pengupasan}

Pisang yang sudah dikukus kemudian dikupas dengan menggunakan pisau anti karat. Pengupasan kulit pisang bertujuan untuk memisahkan kulit dengan daging buah nya dan untuk mengoptimalkan proses selanjutnya. Pengupasan kulit pisang dapat dilakukan dengan cara yang sederhana yaitu dengan pisau.

4. Pengirisan

Pengirisan dilakukan dengan tujuan untuk memperkecil ukuran, juga lebih mudah dalam proses pengeringan. Pengirisan dilakukan dengan menggunakan pisau dengan ketebalan kurang lebih $0,4 \mathrm{~cm}$.

\section{Perendaman}

Irisan buah pisang selanjutnya direndam dalam larutan natrium metabisulfit selama 5 menit. Larutan perendam dibuat dengan melarutkan natrium/kalium metabisulfit sebanyak 2 gram dalam 1 liter air. Jumlah larutan yang dibuat tergantung jumlah irisan pisang yang akan direndam. Fungsi dari perendaman ini yaitu mencegah terjadinya reaksi browning (pencoklatan), karena pada pisang adanya kandungan zat tannin. Zat 
tanin merupakan senyawa yang cepat sekali teroksidasi dan menyebabkan pencoklatan. Pencoklatan ini dapat dicegah melalui proses perendaman.

6. Pembilasan

Setelah dilakukan perendaman dengan natrium metabisulfit kemudian dilakukan pembilasan dengan mengunakan air bersih untuk menghilangkan kotoran yang masih melekat, pembilasan dilakukan dengan menggunakan air yang mengalir.

7. Penirisan

Buah pisang yang telah dibilas lalu dilakukan penirisan dengan cara menyaring menggunakan ayakan selama \pm 10 menit sampai air tersebut tidak bersisa. Penirisan ini dilakukan untuk menghilangkan air sisa pembilasan yang terdapat pada buah pisang.

8. Pengeringan

Proses pengeringan dilakukan untuk mengurangi kadar air yang terkandung dalam buah pisang. Potongan pisang dihamparkan di atas tampah atau nyiru yang anyamannya jarang. Setelah itu dilakukan penjemuran sinar matahari sampai potongan pisang kering. Jika menggunakan proses penjemuran sinar matahari maka waktu yang digunakan selama 2 hari tergantung panas matahari.

9. Penggilingan

Pisang yang telah kering kemudian. digiling menggunakan mesir. penggilingan. Penggilingan dilakukan berulang sebanyak 2 kali agar memperoleh tepung yang maksimal.

10. Pengayakan

Proses pengayakan dilakukan untuk memperoleh ukuran tepung pisang yang seragam, dengan menggunakan ayakan ukuran 80 mesh.

\section{Pembuatan Roti Manis Kukus (Mariana, 2007 yang telah dimodifikasi)}

\section{Pembuatan adonan/pencampuran}

$\begin{array}{ccr}\text { Sesuai } & \text { dengan } & \text { campuran } \\ \text { masing-masing } & \text { perlakuan } & \text { dengan }\end{array}$ ukuran masing-masing tepung pisang 200 gram sehingga memperoleh campuran tepung pisang sebesar 1800 gram dan tepung terigu sebanyak 500 gram dengan memperoleh semua campuran sebesar 4500 gram. Kemudian masing-masing perlakuan ditambah dengan gula pasir 85 gram, garam $1 \mathrm{~g}$, susu bubuk $60 \mathrm{~g}$, fermifan 4 $\mathrm{g}$, margarine $65 \mathrm{~g}, 1$ butir kuning telur dan campur dengan air $100 \mathrm{ml}$. kemudian di mixer hingga terbentuk adonan yang khalis.

\section{Fermentasi I}

Pada proses ini terjadi reaksi antara gula dan ragi sehingga terbentuk gas $\mathrm{CO}_{2}$, alkohol dan asam organik yang menimbulkan bau yang khas. Gas $\mathrm{CO}_{2}$ akan terlihat dengan tanda adonan yang mengembang, sedangkan alkohol dan asam-asam organik ditandai dengan bau yang khas. Setiap adonan 50 gr dibentuk bulat atau sesuai dengan keinginan. Adonan ditutup dengan plastik dan difermentasi selama 30 menit hingga mengembang, penutupan dengan plastik bertujuan untuk mencegah penguapan.

\section{Pemotongan dan Penimbangan (Dividing)}

Proses ini diusahakan dilakukan dengan secepatnya karena proses peragian masih berjalan. Pemotongan dan penimbangan bertujuan agar diperoleh berat dan besar yang seragam dalam produk akhir. Sebelum adonan 
dipotong dan ditimbang, gas yang terbentuk harus dikeluarkan dahulu.

\section{Pembulatan}

Adonan yang telah mengembang kemudian dicetak berbentuk bulatan seperti roti manis kukus dengan berat ukuran 50 gr. Pencetakan adonan ini bertujuan untuk mempermudah proses selanjutnya. Untuk roti manis usahakan pembentukan dan penggulungan dalam keadaan rapat dan padat, dan sambungannya berada dibawah adonan.

\section{Fermentasi II}

Kemudian difermentasi lagi selama 15 menit agar bentuk dan kualitas maksimal. Tempat untuk fermentasi ini harus memiliki panas (34$\left.40^{\circ} \mathrm{C}\right)$ dan kelembaban ruang $(80-85 \%)$ yang stabil.

\section{Isi adonan roti}

Setelah dilakukan fermentasi ke II, kemudian roti dibentuk dan diisi selai nenas didalmnya. Bahan pengisi digunakan sebagai bahan pembantu dalam pembuatan roti manis kukus, agar meningkatkan cita rasa dari roti yang dihasilkan.

\section{Fermentasi III}

Sebelum dikukus, adonan dikembangkan sampai maksimal agar didapatkan produk yang baik. Suhu yang dipakai adalah 35-44 ${ }^{\circ} \mathrm{C}$, kelembaban 80-85\% dan waktu sekitar 15-45 menit.

\section{Pengukusan}

Adonan yang terbentuk dimasukkan kedalam loyang dan dikukus selama 20 menit.

\section{Roti manis kukus}

Setelah pengukusan, roti manis siap disajikan dan dikemas.

\section{Pengamatan}

Parameter yang akan diamati pada penelitian ini meliputi kadar air, kadar abu, kadar protein, dan uji organoleptik terhadap warna, rasa, aroma dan tekstur.

\section{HASIL DAN PEMBAHASAN}

\section{Kadar Air}

Kadar air adalah persentase kandungan air berdasarkan berat basah (wet basis) atau berdasarkan berat kering (dry basis). Kadar air berat basah mempunyai batas maksimum teoritis sebesar $100 \%$, sedangkan kadar air berdasarkan berat kering dapat lebih dari $100 \%$ (Anonim, 2010)

Dari hasil analisis statistik yang dilakukan tentang studi pembuatan roti manis kukus dari campuran tepung terigu dengan tepung pisang nangka terhadap kadar air roti manis kukus data disajikan pada Tabel 1.

Tabel 1. Rata-Rata Kadar Air Roti Manis Kukus Berdasarkan Perlakuan Campuran Tepung Pisang Nangka dengan Tepung Terigu.

\begin{tabular}{|c|l|}
\hline \multicolumn{1}{|c|}{ Perlakuan } & Kadar Air \% \\
\hline C (Tepung Pisang Nangka 30\%: Tepung Terigu 70\%) & $36.915 \mathrm{a}$ \\
D (Tepung Pisang Nangka 40\%: Tepung Terigu 60\%) & $35.510 \mathrm{~b}$ \\
B (Tepung Pisang Nangka 20\%: Tepung Terigu 80\%) & $33.025 \mathrm{~b}$ \\
E (Tepung Pisang Nangka 50\%: Tepung Terigu 50\%) & $31.901 \mathrm{~b}$ \\
A (Tepung Pisang Nangka 10\%: Tepung Terigu 90\%) & $29.009 \mathrm{~b}$ \\
\hline
\end{tabular}

Keterangan : angka-angka pada jalur atau kolom yang sama diikuti oleh huruf yang sama berbeda nyata menurut uji Lanjut Tukey pada taraf nyata 5\%. 
Berdasarkan Tabel 1 dapat dilihat bahwa kadar air roti manis tertinggi terdapat pada perlakuan C : (Pisang nangka $30 \%$ :Tepung terigu $70 \%$ ) yaitu $36.915 \%$, Sedangkan kadar air terendah dapat dilihat pada perlakuan A: (Tepung pisang nangka 10\% : Tepung terigu 90\%) yaitu 29.009\%. Analisa sidik ragam perlakuan terhadap kadar air roti manis kukus yang dihasilkan menunjukkan bahwa hasil yang diperoleh memberikan pengaruh nyata. Oleh sebab itu perlu dilakukan uji lanjut menggunakan uji lanjut tukey pada taraf nyata $5 \%$. Berdasarkan sidik ragam pada menunjukkan nilai $\mathrm{F}$ hitung 3,57 lebih besar dari pada nilai $\mathrm{F}$ Tabel $5 \%$ sebesar 3,47 . Hal ini menunjukkan bahwa setiap perlakuan memberikan pengaruh nyata yang semakin tinggi persentase tepung terigu kadar air semakin rendah dan disebabkan karena tepung terigu dapat menyerap air dengan kapasitas yang besar. Menurut Desrosier (2008), bahwa tepung terigu mengandung kurang lebih 0,5 sampai $0,8 \%$ pentosa yang larut dalam air. Zat ini memiliki sifat kelarutan dalam air sehingga menghasilkan larutan yang sangat kental. Terjadinya pengentalan disebabkan tepung mempunyai kemampuan menyerap air dan pendapat Shahzadi (2005), menyatakan bahwa Peningkatan kadar protein berpengaruh pada peningkatan daya serap air. Hal ini disebabkan terjadinya peningkatan gugus pentosa yang dapat meningkatkan daya ikat terhadap air sehingga kadar air menurun. Maka dalam penghitungan analisis kadar air semakin tinggi tepung terigu yang ditambahkan maka kadar air roti manis semakin menurun. Kemampuan menyerap air yang besar pada pati diakibatkan molekul pati mempunyai jumlah gugus hidroksil yang sangat besar (Winarno, 2002). Bila suspensi pati dalam air dipanaskan, beberapa perubahan selama terjadinya gelatinisasi dapat diamati. Mula-mula suspensi pati yang keruh seperti susu tiba-tiba mulai menjadi jernih pada suhu tertentu, tergantung jenis pati yang digunakan. Terjadinya translusi larutan pati tersebut diikuti pembengkakkan granula. Bila energi kinetik molekulmolekul air menjadi lebih kuat daripada daya tarik-menarik antara molekul pati di dalam granula, air dapat masuk ke dalam butir-butir pati. Hal inilah yang menyebabkan bengkaknya granula. Jumlah gugus hidroksil dalam molekul pati yang besar menyebabkan kemampuan pati menyerap air pun besar (Winarno, 2002).

Pati akan mengalami denaturasi jika diberi perlakuan panas, granula pati tidak larut dalam air dingin tetapi akan mengembang dalam air hangat. Pengembangan granula pati bersifat dapat balik jika pemanasan yang diberikan pada pati belum melewati suhu gelatinisasi. Pengembangan granula pati disebabkan oleh penetrasi molekul pati terperangkap dalam molekul-molekul amilosa atau amilopektin (Basuki, 1988). Dimana SNI untuk kadar air roti manis kukus max $40 \%$,.

Kadar air sangat berpengaruh terhadap mutu bahan pangan, dan hal ini merupakan salah satu sebab mengapa didalam pangan air tersebut sering dikurangi atau dikeluarkan dengan cara penguapan atau pengentalan atau pengeringan. Kandungan air sangat berpengaruh terhadap konsistensi bahan pangan (Winarno, 2002).

\section{Kadar Abu}

Menurut Winarno (2002) kadar abu merupakan zat organik ataupun unsur-unsur mineral yang terdapat dari sisa pembakaran pada suatu bahan makanan, menurut Berlina, (1997) formula yang diolah dengan suhu tinggi 
telah menurunkan kadar air produk, sehingga kandungan bahan padatan seperti abu dan mineral meningkat.

Dari hasil analisis statistik yang dilakukan tentang studi pembuatan roti manis kukus dari campuran tepung terigu dengan tepung pisang nangka terhadap kadar abu roti manis data disajikan pada Tabel 2.

Tabel 2. Rata-Rata Kadar Abu Roti Manis Kukus Berdasarkan Perlakuan Campuran Tepung Pisang Nangka dengan Tepung Terigu.

\begin{tabular}{|l|c|}
\hline \multicolumn{1}{|c|}{ Perlakuan } & $\begin{array}{c}\text { Kadar } \\
\text { Abu \% }\end{array}$ \\
\hline E (Tepung Pisang Nangka 50\% : Tepung Terigu 50\%) & 0.8217 \\
D (Tepung Pisang Nangka 40\% : Tepung Terigu60\%) & 0.7301 \\
C (Tepung Pisang nangka 30\% : Tepung Terigu 70\%) & 0.6444 \\
B (Tepung Pisang Nangka 20\% : Tepung Terigu 80\%) & 0.6338 \\
A (Tepung Pisang Nangka 10\%: Tepung Terigu 90\%) & 0.5387 \\
\hline
\end{tabular}

Berdasarkan Tabel 2 dapat dilihat bahwa studi pembuatan roti manis kukus dari campuran tepung terigu dengan tepung pisang nangka terhadap kadar abu tidak memberikan pengaruh nyata terhadap roti manis yang dihasilkan. kadar abu roti manis kukus persentase tertinggi terdapat pada perlakuan $\mathrm{E}$ : (Tepung pisang 50\%: Tepung terigu $50 \%$ ) yaitu $0,8217 \%$ sedangkan hasil rata-rata terendah dapat dilihat pada perlakuan A : (Tepung pisang nangka $10 \%$ : Tepung terigu 90\%) yaitu $0,5387 \%$. Tinggi rendahnya kadar abu roti manis kukus yang dihasilkan dipengaruhi oleh pencampuran tepung pisang nangka, Semakin tinggi tepung pisang yang ditambahkan maka semakin tinggi kadar abu. Dengan tingginya kadar abu dari tepung pisang akan mempengaruhi kadar abu roti manis yang dihasilkan, semakin tinggi persentase tepung pisang nangka yang ditambahkan maka akan semakin tinggi kadar abu dari roti manis. Hal ini sesuai dengan pendapat Suyanti Sutuhu dan
Ahmad Supriyadi (1999), bahwa kadar abu tepung pisang berkisar 3,2\% dan kadar abu tepung terigu berkisar 1,3\%. Kadar abu dari semua perlakuan memenuhi standar SNI yaitu $3 \%$ dan SNI 12-08-2005 dari penelitian yang dilakukan bahwa kadar abu berkisar $0,82 \%-0,53 \%$.

\section{Kadar Protein}

Menurut Winarno (1992), kadar protein merupakan zat makanan yang amat penting bagi tubuh yang berfungsi sebagai zat pembangun dan pengatur pada tubuh. Kadar protein dapat mengalami kerusakan yang disebabkan oleh reaksi kimia dengan asam atau basa, guncangan dan sebab-sebab yang dikenal dengan proses penggumpalan atau perekrutan.

Dari hasil analisis statistik yang dilakukan tentang studi pembuatan roti manis kukus dari campuran tepung terigu dengan tepung pisang nangka terhadap kadar protein roti manis kukus data disajikan pada Tabel 3. 
Tabel 3. Rata-Rata Kadar Protein Roti Manis Kukus Berdasarkan Perlakuan Campuran Tepung Pisang Nangka dengan Tepung Terigu

\begin{tabular}{|c|c|}
\hline \multicolumn{1}{|c|}{ Perlakuan } & $\begin{array}{c}\text { Kadar } \\
\text { Protein } \\
\text { \% }\end{array}$ \\
\hline A (Tepung Pisang Nangka 10\%: Tepung Terigu 90\%) & 9.9415 \\
C (Tepung Pisang Nangka 30\%: Tepung Terigu 70\%) & 9.7162 \\
E (Tepung Pisang Nangka 50\%: Tepung Terigu 50\%) & 9.6681 \\
B (Tepung Pisang Nangka 20\%: Tepung Terigu 80\%) & 8.9079 \\
D (Tepung Pisang Nangka 40\%: Tepung Terigu 60\%) & 7.5586 \\
\hline
\end{tabular}

Dari Tabel 3 dapat dilihat bahwa studi pembuatan roti manis dari campuran tepung terigu dengan tepung pisang nangka terhadap kadar protein roti manis kukus tidak memberikan pengaruh nyata terhadap roti manis yang dihasilkan. .Kadar protein roti manis kukus tertinggi adalah $9.9415 \%$ yang diperoleh pada perlakuan A (Tepung Pisang Nangka 10\% : Tepung Terigu $90 \%$ ) sedangkan kadar protein roti manis terendah diperoleh pada perlakuan D (Tepung Pisang Nangka 40\% : Tepung Terigu $60 \%$ ) yaitu $7.5586 \%$. Hal ini menunjukkan bahwa pencampuran tepung terigu dengan tepung pisang nangka yang ditambahkan tidak berpengaruh terhadap kandungan protein roti manis kukus yang dihasilkan. Semakin tinggi persentase tepung terigu maka protein roti yang dihasilkan semakin tinggi. Hal ini disebabkan karena pada tepung pisang kandungan proteinnya lebih rendah dibandingkan kadar protein tepung terigu. Kadar protein tepung pisang hanya $3,36 \%$ sampai $4,12 \%$, sedangkan kadar protein tepung terigu berkisar antara $8 \%$ sampai $9 \%$ (Antarlina et al 2004). Protein yang yang terkandung didalam roti manis kukus dipengaruhi oleh bahan penyusun didalam pembuatan bahan penyusun meliputi tepung terigu, tepung pisang, telur, gula dan bahan pengembang roti, dari semua bahan penyusun tersebut ada beberapa bahan yang kaya akan protein diantaranya tepung terigu, telur, didalam 100 gram telur mengandung protein sebanyak 12 , 8 gram sedangkan pada tepung terigu 7 $9 \%$ (Pamungkas S, 2008).

$$
\text { Pada hasil penelitian }
$$
menunujukkan bahwa kadar protein tertinggi pada perlakuan A, sementara terendah pada perlakuan D, kadar protein tidak sesuai dengan literatur yang menyatakan tinggi nya penambahan tepung terigu otomatis protein semakin tinggi, sementara dari hasil analisis yang diperoleh hasil tidak sesuai dengan literatur, hal ini diduga faktor sebelum analisa seperti faktor transfortasi dan waktu sebelum analisa akan dapat mempengaruhi kadar protein. Disamping itu faktor panas baik disaat pengukusan dan lama transfortasi akan menyebabkan terjadinya denaturasi protein, sesuai dengan pendapat Stroker (2010), bahwa denaturasi protein terjadi akibat adanya perubahan struktur karakteristik bentuk akibat dari gangguan interaksi sekunder, tersier dan struktural seperti suhu, penambahan garam dan lain-lain, karena fungsi biokimia protein tergantung pada tiga dimensi bentuknya atau susunan senyawa yang terdapat pada asam amino.

Menurut Winarno (1992), kadar protein merupakan zat makanan yang amat penting bagi tubuh yang berfungsi sebagai zat pembangun, dan pengatur 
pada tubuh. Kadar protein dapat mengalami kerusakan yang disebabkan oleh panas, reaksi kimia dengan asam atau basa, guncangan dan sebab-sebab lain yang dikenal dengan proses penggumpalan atau pengkerutan.

\section{KESIMPULAN DAN SARAN}

\section{Kesimpulan}

Dari hasil penelitian Studi

Pembuatan Roti Manis Kukus dari Campuran Tepung Terigu dengan Tepung Pisang Nangka dapat disimpulkan bahwa: perlakuan yang terbaik diperoleh pada perlakuan A (Tepung Pisang Nangka 10\% : Tepung Terigu 90\%) dengan kadar air 29,00\%, kadar abu 0,54 \%, dan kadar protein 9,94 $\%$, dan uji organoleftik warna $3,20 \%$, aroma $3,45 \%$, tekstur $2,95 \%$ dan rasa $2,90 \%$ dan telah memenuhi Standar Nasional untuk roti manis kukus (SNI 01-3840-1995).

\section{Saran}

Sebaiknya dilakukan penelitian tepung lain sebagai pengganti tepung terigu untuk membandingkan daya terima dan pengaruh terhadap roti yang dihasilkan.

\section{DAFTAR PUSTAKA}

Anonim.2010.Bahantambahan.http://ww w.tokocsc.com/Bahan_Utama_R oti_Manis_\&_Donat.html. Akses tanggal 2 April 2010, Makassar 2011.

Ragi.http://id.wikipedia.org/wiki/ Ragi. Makassar.

Anonim. 2011. Mengenal Berbagai Macam Roti http//wordpress.com.Akses tanggal 02 April 2011. Makasar.
Amarilia. H. 2010. Studi pembuatan roti manis dan pancake dari campuran tepung terigu dan tepung sukun. Universitas Muhammadiyah Malang.

Astawan, M. 2004 Kandungan Serat Dan Gizi Pada Roti Unggul Mie Dan Nasi http://www.gizi.net (akses 10 januari 2011)

Arifin, S 2011. Studi Pembuatan Roti dengan Substitusi Tepung Pisang Kepok (Musa Paradisiaca Formatyica). Skripsi, Program Studi Ilmu dan Teknologi Pangan Jurusan Teknologi Pertanian Fakultas Pertanian. Universitas Hasanuddin. Makassar.

Berlina. 1997. Pemanfaatan Ampas Kelapa Untuk Makanan Rendah Kalori Jurnal Penelitian Tanaman Industry. Bogor.

BPS. 2009. Indragiri Hilir Dalam Angka.

Kantor Dinas Pertanian Kabupaten Indragiri Hilir, Tembilahan.

BPS. 2010. Indragiri Hilir Dalam Angka.

Kantor Dinas Pertanian

Kabupaten Indragiri Hilir,

Tembilahan.

BPS. 2011. Indragiri Hilir Dalam Angka.

Kantor Dinas Pertanian

Kabupaten Indragiri Hilir, Tembilahan.

De Man J.M. 1997. Kimia Makanan. Institut Terhadap Pertumbuhan Bibit Mahkota Dewa-Phaleria macrocarpa, di Polibag, Jurnal Akta Agrosia (7) 2 : 72-75.

Departemen Perindustrian RI. (1995). Tepung Terigu Sebagai Bahan Makanan Standar Nasional Inonesia. 